\title{
Study on Ecological Management Method of Rural River
}

\author{
Aichen JIA \\ School of Hydraulic Engineering \\ Dalian University of Technology \\ Dalian, China \\ E-mail: jiaac@126.com \\ Jinjuan FAN \\ Hydrologic Station of Wenzhou City \\ Wenzhou, China \\ E-mail: fjdlut@163.com
}

\author{
Yanping FAN \\ School of Hydraulic Engineering \\ Dalian University of Technology \\ Dalian, China \\ E-mail: fyp2017@163.com
}

\author{
Jianwei DONG \\ Hydraulic Research Institute of Jilin Province \\ Chanchun, China \\ E-mail: jlslsy@tom.com
}

\begin{abstract}
In order to solve the problem of river water pollution and river bank collapse in rural areas, in this paper, the ecological management project of Heidingzi River in Changchun City is taken as an example to study the design of river structure and the optimization of ecological revetment. In the process of structural form design, the river sections are divided into conservation area, landscape area and protection area in order to construct ecological river channel structure form, according to the river condition and the surrounding environment. In the process of the optimization of ecological revetment, the fuzzy analytic hierarchy process was used to optimize the plan. The results showed that the ecological concrete, stone cage ladder cuttings and gabion barricade were adopted in the conservation section, landscape area and protection area respectively. The purpose of this paper is to provide technical support for the ecological management of rural rivers.
\end{abstract}

Keywords-rural rivers; river structure; ecological revetment; fuzzy analytic hierarchy process

\section{INTRODUCTION}

In recent years, river water pollution is serious in many rural areas. River bank slope is washed and collapsed seriously, resulting in the normal function of flood control and drainage is weakened[1]. So river ecological management has become an urgent problem to be solved at this stage. Diversity of river morphology is the basis for maintaining species diversity in river ecosystems, while species diversity is the guarantee for the healthy development of river ecosystems. Therefore, the design of river structure is the most basic process in river ecological management, while the ecological revetment is the key to eco-river course construction.

In this paper, the ecological management project of Heidingzi River in Changchun City is taken as an example to study the design of river structure and the optimization of ecological revetment.

\section{PROJECT OVERVIEW}

The project of Heidingzi River is located at the downstream of Heidingzi Reservoir, starting at Jiaotong
Bridge, and ending at $280 \mathrm{~m}$ upstream of Shanzuizi Sluice The length of the river centerline is $6.6 \mathrm{~km}$, as shown in Fig. 1.

Heidingzi River is $30.4 \mathrm{~km}$ long, with an average gradient of $2.5 \%$. Large area of farmland and many villages are located on both sides of the river, whose water is polluted severely and bank slope is not protected. In order to improve the water quality, prevent the floods from scouring the channel, destroying the cultivated land and endangering the lives and property of the residents on both sides of the river, it is imperative to carry out ecological management of the riverway and riverside.

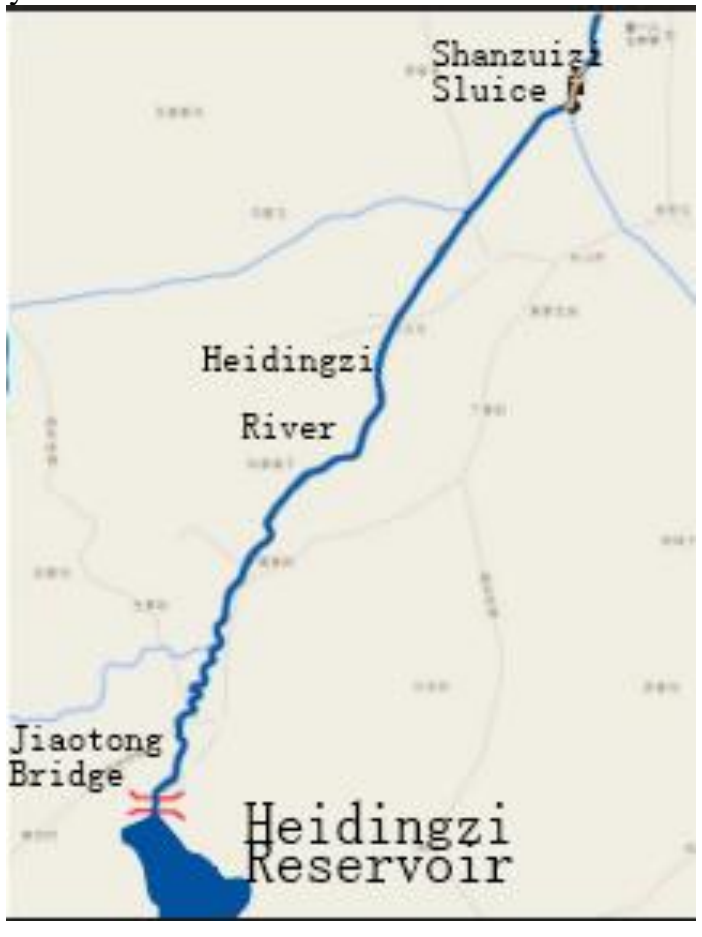

Figure 1. Location of project.

\section{DIVISION OF ENGINEERING}

According to the size of the flow, the degree of erosion damage, natural curvature, the environment on both sides of 
the river and other factors, the management section from upstream to downstream of the Heidingzi River is divided into three sections, namely: conservation area, landscape area, and protection areas, as shown in Fig. 2. Different types of revetment are adopted depending on the characteristics of each area[2].

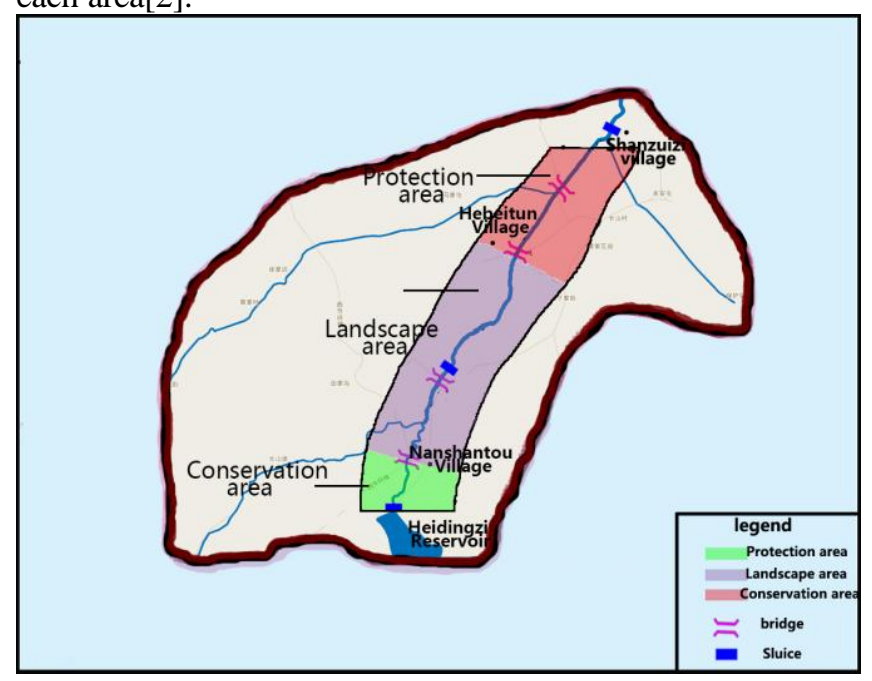

Figure 2. Ecological management plan of Heidingzi River.

\section{A. Conservation Area}

The river is about $700 \mathrm{~m}$ long from Jiaotong Bridge, which is located at the beginning of the governance area to Nanshantou Village. It is surrounded by large area of farmland and a small number of villages. In this area, no tributary runs in and the river flow is so small that river erosion is not serious. Focusing on restoration of natural ecological functions of river and on account of the landscape less demanding, we define this area as conservation area.

\section{B. Landscape Area}

The river is about $4000 \mathrm{~m}$ long from Nanshantou Village to Hebeitun Village and the riverbed is generally S-shaped distribution, with width $12.0 \mathrm{~m} \sim 20.0 \mathrm{~m}$ and depth $0.5 \mathrm{~m} \sim 1.0 \mathrm{~m}$. There is a tributary to import, and the flow is larger which lead to a little serious erosion and siltation. Besides, there are many villages on both sides of the river, with high landscape and hydrophilic requirements. This area is the focus of the governance project, which is defined as landscape area.

\section{Protection Area}

The river is about $1900 \mathrm{~m}$ long from the Hebeitun village to $280 \mathrm{~m}$ upstream of Shanzuizi Sluice which is located at the end of governance area. And the riverside is straightest, with width $15.0 \mathrm{~m} \sim 20.0 \mathrm{~m}$ and depth $0.50 \mathrm{~m} \sim 1.00 \mathrm{~m}$. There are tributarys to import and the flow is largest so that lead to serious erosion and siltation. The river is surrounded by mostly farmland and the landscape requirement is low. Focusing on solving the problem of bank erosion and collapse, we define this area as protection area.

\section{Study on Ecological Management of RuRAL RIVER STRUCTURE}

\section{A. Calculate Design Flood}

The design of river channel structure should be carried out under the condition of meeting the flood control standard. Therefore, the design flood of the treatment section should be deduced before design. The control area of the project is only $47.5 \mathrm{~km}^{2}$, and the flow data is not enough, but the rainstorm data is more. So it is suitable to deduce the design flood with the rainstorm data[3].

According to the size of the tributaries and the subarea, there are three control points for the design flood calculation, namely Nanshantou, Hebeitun and Shanzuizi, divided into three sections of the design flood calculation.

The flood control standard for this project is a flood of 10 years. According to the flood control principle of Heidingzi reservoir, the flow of discharge in the case of a flood in ten years is not more than $10 \mathrm{~m}^{3} / \mathrm{s}$. The discharge of Heidingzi reservoir is overlapped with the interval peak flow of each control point, and the design peak flow of each control point in the project area is obtained. The results are shown in Tab. 1.

TABLE I. Result of DESign Flood PeAK Discharge

\begin{tabular}{|l|c|c|c|}
\hline control point & Nanshantou & Hebeitun & Shanzuizi \\
\hline $\mathrm{P}(10 \%)\left(\mathrm{m}^{3} / \mathrm{s}\right)$ & 19.90 & 49.30 & 78.80 \\
\hline
\end{tabular}

\section{B. Structural Form Design}

\section{1) Meandering construction}

Compared with the straight river, meandering rivers make the habitats richer and varieder, expand the habitat area, and reduce soil erosion[4]. This scheme retains the original meandering morphology of the river, only to broaden and deepen as needed. But the conservation area and the landscape area where the river meandering seriously need to be optimized the transformation to reduce the impact of erosion on the bank slope and make the river flood discharged more smoothly.

\section{2) Pool and riffle construction}

In natural rivers alternate pool and riffle can provide water with different velocity and habitat. It is conducive to the aeration of the river water, and this enriches the biological diversity of rivers. It can also greatly increase the specific surface area of the riverbed and subsequently increase the biological number attached to the riverbed, which is in favor of the improvement of self-purification capacity[5]. This scheme adopts the artificial stacking stones, with the help of water erosion to restore the pool and riffle structure. The number of pool and riffle is determined according to the meandering nature of the river, and the distance between the adjacent constructions is about $100 \mathrm{~m}$.

\section{3) Cross-sectional design}

The river cross-section is adopted duplex structure with gentle slope[2]. The original steep bank slope is reduced to a gentle slope of 1:2.5, and banks with a gentle natural slope maintain the original slope. The size of the section is 
determined by the formula of uniform water flow in open channel.
Hydraulic computation result of each area is shown in Tab. 2 and the planning maps are shown in Fig. 3 5.

TABLE II. HYDRAULIC COMPUTATION RESULT OF EACH SECTION

\begin{tabular}{|c|c|c|c|c|c|c|c|}
\hline \multirow{2}{*}{$\begin{array}{c}\text { areas } \\
\text { Conservation area }\end{array}$} & Length(km) & Slope(\%) & Bottom width(m) & \multicolumn{2}{|c|}{ Design floods } & $\begin{array}{c}\text { Dike } \\
\text { Height(m) }\end{array}$ \\
\cline { 5 - 7 } Distance(m) \\
\hline landscape area & 4.14 & 1.53 & 10 & 19.9 & 1.4 & 2 \\
\hline Protection area & 6.67 & 1.95 & 11 & 49.3 & 2 & 2.6 & 24 \\
\hline
\end{tabular}

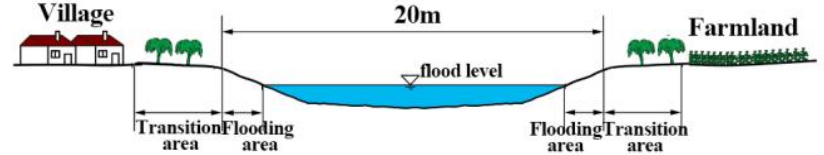

Figure 3. Cross-section planning map of Conservation area.

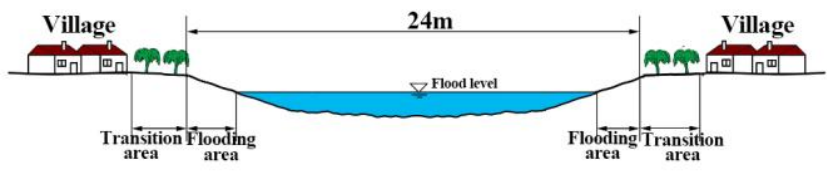

Figure 4. Cross-section planning map of Landscape area.

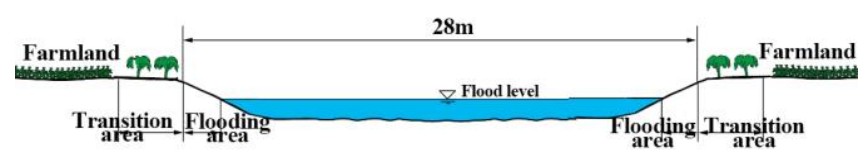

Figure 5. Cross-section planning map of Protection area.

\section{StUdy ON Optimization OF ECOLOGICAL REVETMENT IN RURAL RIVER}

\section{A. Revetment Form}

The selection of revetment form needs to consider the principle of adjusting measures to local conditions and materials, in addition to take account of the geological conditions, embankment materials, ecological restoration, construction conditions and so on[6]. In recent years, ecological concrete, Reno Mattress and other more advanced technology in river regulation has achieved good results, coupled with the location stone and wood rich in resources, therefore, the initial form of revetment is determined as stone cage ladder cuttings, ecological concrete, timber pile and riprap, gabion barricade, half-dry stone-laying, plant revetment, as shown in Fig. 6.

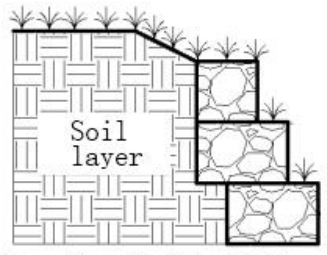

Stone Cage Ladder Cuttings

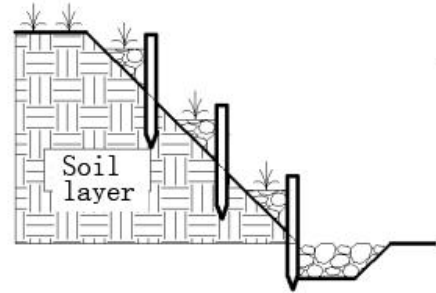

Timber Pile and Riprap

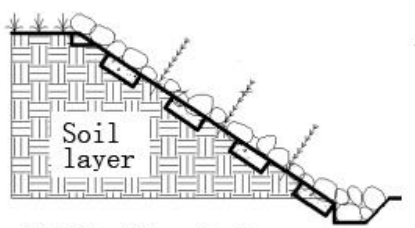

Half-dry Stone-laying

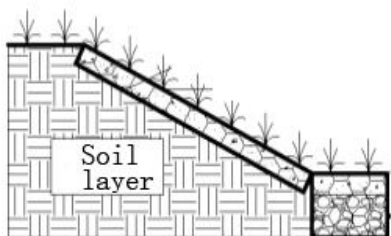

Ecological Concrete

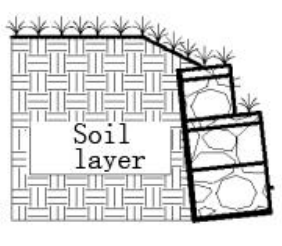

Gabion Barricade

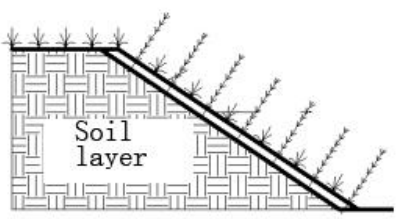

Plant Revetment
Figure 6. Ecological Revetments Schematic Diagram

\section{B. Scheme Optimization}

In this paper, fuzzy analytic hierarchy process is used to construct the hierarchical structure model of ecological revetment technology, and the optimal revetment forms are selected for different areas of Heidingzi River.

Analytic hierarchy process (AHP) is a multi-criteria decision-making method proposed in the 1970s [7-9]. It expresses a complex problem as an ordered hierarchical structure, which can be used to judge the quality of the decision-making plan by people's judgment. It is suitable for multi-objective decision-making problems with complex hierarchical structure. This method can deal with the qualitative and quantitative factors in decision-making. It is practical, systematic and concise. But when judging the judgment matrix, the subjective judgments and preferences have a great influence on the decision-making results. In this paper, fuzzy analytic hierarchy process (FAHP) [10-11], 
which combines AHP with fuzzy comprehensive evaluation (FCE)[12], is used to study the optimal selection of ecological revetment, to avoid the influence of subjective judgment and preference of individuals on the choice of revetment forms.

1) The establishment of index system:

The above six kinds of ecological revetments can make the stability and stress meet the requirements. The choice of revetment form mainly consider the requirements of different management areas on engineering safety, economy and ecological landscape. The establishment of a specific index system is shown in Fig. 7.

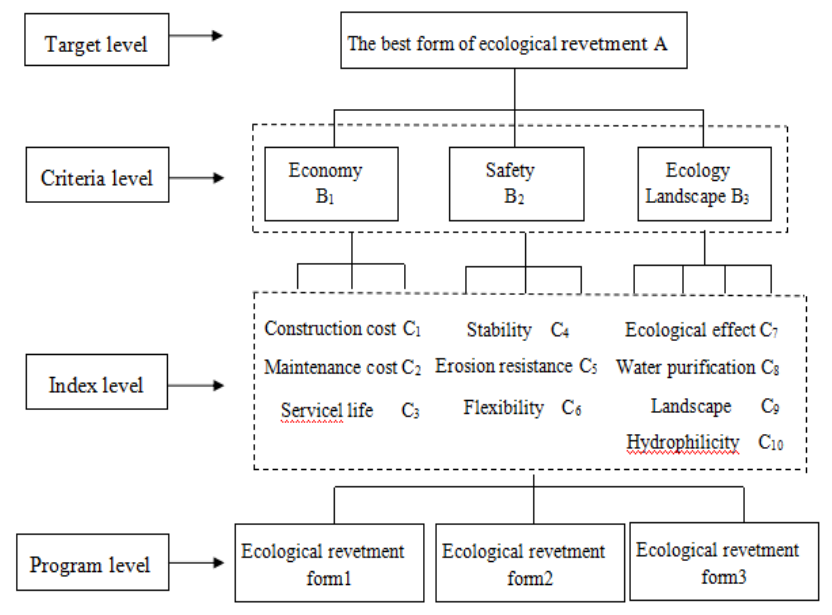

Figure 7. Ecological revetment optimization index system diagram.

2) Determine the index weights:

In order to judge the relative importance of each index, this paper adopts Delphi method and analytic hierarchy process.[13] According to the principle of pairwise comparison, the important factors of criterion layer are judged according to 1-9 scale, and the judgment matrix is obtained. Then the eigenvector should be calculated and normalized to obtain the relative weight. The weight is determined according to the characteristics of different sections of the river and the surrounding environment, respectively. The judgment matrices and weight of three areas are shown in Tab. 3 5.

TABLE III. JUDGMENT MATRIX AND WEIGHT OF CONSERVATION AREA

\begin{tabular}{|c|c|c|c|c|}
\hline & B1 & B2 & B3 & W1 \\
\hline B1 & 1 & $1 / 3$ & $1 / 4$ & 0.1260 \\
\hline B2 & 3 & 1 & 1 & 0.4161 \\
\hline B3 & 4 & 1 & 1 & 0.4579 \\
\hline
\end{tabular}

TABLE IV. JUdGMENT MATRIX AND WEIGHT OF LANDSCAPE AREA

\begin{tabular}{|c|c|c|c|c|}
\hline & B1 & B2 & B3 & W2 \\
\hline B1 & 1 & $1 / 3$ & $1 / 5$ & 0.1094 \\
\hline B2 & 3 & 1 & $1 / 2$ & 0.3090 \\
\hline B3 & 5 & 2 & 1 & 0.5816 \\
\hline
\end{tabular}

TABLE V. Judgment MATRIX AND Weight of PRotection AREA

\begin{tabular}{|c|c|c|c|c|}
\hline & B1 & B2 & B3 & W3 \\
\hline B1 & 1 & $1 / 3$ & $1 / 2$ & 0.1692 \\
\hline B2 & 3 & 1 & 1 & 0.4434 \\
\hline B3 & 2 & 1 & 1 & 0.3874 \\
\hline
\end{tabular}

In the same way, the importance factor of the index layer is judged and the consistency test is carried out to determine the index weight. The judgment matrix and the calculation results are shown in Tab. 6.

TABLE VI. JUdGMENT MATRIX AND WEIGHT OF INDEX LEVEL

\begin{tabular}{|c|c|c|c|c|c|c|}
\hline \multirow{4}{*}{ Economy } & & C1 & $\mathrm{C} 2$ & $\mathrm{C3}$ & & W1' \\
\hline & CI & 1 & 7 & 3 & & 0.6694 \\
\hline & $C 2$ & $1 / 7$ & 1 & $1 / 3$ & & 0.0879 \\
\hline & C3 & $1 / 3$ & 3 & 1 & & 0.2426 \\
\hline \multirow{4}{*}{ Safety } & & $\mathrm{C} 4$ & C5 & C6 & & W2' \\
\hline & $C 4$ & 1 & 2 & 5 & & 0.5816 \\
\hline & C5 & $1 / 2$ & 1 & 3 & & 0.3090 \\
\hline & C6 & $1 / 5$ & $1 / 3$ & 1 & & 0.1094 \\
\hline \multirow{5}{*}{$\begin{array}{c}\text { Ecology } \\
\text { Landscape }\end{array}$} & & C7 & C8 & C9 & C10 & $\mathbf{W 3}^{\prime}$ \\
\hline & C7 & 1 & 2 & 4 & 5 & 0.5177 \\
\hline & C8 & $1 / 2$ & 1 & 2 & 2 & 0.2444 \\
\hline & C9 & $1 / 4$ & $1 / 2$ & 1 & 1 & 0.1222 \\
\hline & $\begin{array}{c}C 1 \\
0\end{array}$ & $1 / 5$ & $1 / 2$ & 1 & 1 & 0.1157 \\
\hline
\end{tabular}

\section{3) Determine the fuzzy evaluation matrix:}

In this paper, seven experts were invited to rate the advantages and disadvantages of each factor in the six types of bank revetment, after which the results were statistically analyzed. Each factor on the index level has an expert approval rate for each level, which is its membership degree. The evaluation has 5 levels, and that is, $\mathrm{V}=$ \{very poor, poor, general, good, very good $\}$. The fuzzy evaluation matrices of the stone cage ladder cuttings are:

$$
\begin{aligned}
\mathrm{R}_{1} & =\left[\begin{array}{ccccc}
0 & 1 / 7 & 3 / 7 & 2 / 7 & 1 / 7 \\
0 & 2 / 7 & 3 / 7 & 1 / 7 & 1 / 7 \\
0 & 0 & 1 / 7 & 5 / 7 & 1 / 7
\end{array}\right] \\
\mathrm{R} 2 & =\left[\begin{array}{ccccc}
0 & 1 / 7 & 2 / 7 & 3 / 7 & 1 / 7 \\
0 & 2 / 7 & 2 / 7 & 2 / 7 & 1 / 7 \\
0 & 0 & 1 / 7 & 4 / 7 & 2 / 7
\end{array}\right] \\
\mathrm{R} 3 & =\left[\begin{array}{lllll}
0 & 0 & 1 / 7 & 2 / 7 & 4 / 7 \\
0 & 0 & 1 / 7 & 4 / 7 & 2 / 7 \\
0 & 0 & 1 / 7 & 5 / 7 & 1 / 7 \\
0 & 0 & 2 / 7 & 2 / 7 & 3 / 7
\end{array}\right]
\end{aligned}
$$

4) Comprehensive evaluation

Evaluation matrix of criterion level: 


$$
\mathrm{B}_{\mathrm{i}}=\mathrm{W}_{\mathrm{i}}^{\prime} \cdot \mathrm{R}_{\mathrm{i}}
$$
layer:

Comprehensive evaluation matrix of each sector in target

$$
\mathrm{A}=\mathrm{W} \cdot \mathrm{R}=\mathrm{W}_{\mathrm{i}}\left[\begin{array}{l}
\mathrm{B}_{1} \\
\mathrm{~B}_{2} \\
\mathrm{~B}_{3}
\end{array}\right]
$$

The obtained evaluation vector is further quantized by transforming the evaluation vector into a specific value for comparison and ranking. In this paper, the quantization values of each element in the set of reviews are defined as $\mathrm{V}_{1}=20, \mathrm{~V}_{2}=40, \mathrm{~V}_{3}=60, \mathrm{~V}_{4}=80$ and $\mathrm{V}_{5}=100$, and $\mathrm{A}$ and $\mathrm{V}$ are multiplied to obtain the comprehensive evaluation result $\mathrm{G}=\mathrm{A} \cdot \mathrm{V}^{\mathrm{T}}$.

Taking the staircase of stone cage ladder cuttings as an example, the comprehensive evaluation scores in different sections are: conservation area: $\mathrm{G}_{1}=77.5681$, landscape area: $\mathrm{G}_{2}=79.3672$, protection area: $\mathrm{G}_{3}=76.5392$.

Similarly, the comprehensive score of other revetment forms in different areas can be obtained, as shown in Tab. 7 .

TABLE VII. COMPREHENSIVE EVALUATION RESULT OF DIFFERENT SECTION OF 6 REVETMENT FORMS

\begin{tabular}{|c|c|c|c|}
\hline Revetment form & $\begin{array}{c}\text { Conservation } \\
\text { area }\end{array}$ & $\begin{array}{c}\text { Landscape } \\
\text { area }\end{array}$ & $\begin{array}{c}\text { Protection } \\
\text { area }\end{array}$ \\
\hline $\begin{array}{c}\text { stone cage } \\
\text { ladder cuttings }\end{array}$ & 77.5681 & 79.3672 & 76.5392 \\
\hline $\begin{array}{c}\text { ecological } \\
\text { concrete }\end{array}$ & 78.7898 & 75.0867 & 74.6018 \\
\hline gabion barricade & 76.0157 & 75.4882 & 78.3218 \\
\hline $\begin{array}{c}\text { timber pile and } \\
\text { riprap }\end{array}$ & 76.8634 & 78.2103 & 75.8177 \\
\hline $\begin{array}{c}\text { half-dry } \\
\text { stone-laying }\end{array}$ & 77.3852 & 76.5484 & 74.5244 \\
\hline plant revetment & 74.5978 & 75.0261 & 73.3891 \\
\hline
\end{tabular}

\section{4) Analysis and discussion:}

It can be seen from Tab. 7 that the comprehensive score of ecological concrete revetment is the highest in the conservation area, and stone cage ladder cuttings is the highest in the landscape area, and gabion barricade is the highest in the protection area. Therefore, it is recommended to use ecological concrete, stone cage ladder cuttings, and gabion barricade respectively in the conservation area, landscape area and protection area.

In the selection of ecological revetment form, the construction cost is not the only decisive factor, and other factors such as service life, management and maintenance, engineering safety and ecological landscape should be taken into consideration. Fuzzy analytic hierarchy process is a practical and effective method for engineering project with both quantitative and qualitative indexes. It combines fuzzy comprehensive evaluation and analytic hierarchy process to avoid the influence of individual subjective judgments and preferences, and ensure the scientific and rational decisionmaking.

\section{CONCLUSION}

In this paper, the ecological management method of Heidingzi River has been designed. According to the river condition and the surrounding environment, the management section was divided into three sections: conservation area, landscape area and protection area. The natural meandering of the original river course was followed and retained. The pool and riffle structure was constructed by placing artificial stacking stones. The steep bank slope was reduced to a gentle slope complex structure, widening and deepening the siltation channel, improving the ability of river flood control and drainage, enlarging the habitat area, increasing the biodiversity and enhancing ecological function of river. In the aspect of ecological revetment, this paper summarized the types of ecological revetment and built the optimal model of ecological revetment based on fuzzy analytic hierarchy process, and chose suitable ecological revetment form to ensure the safety, economy and ecological landscape of the project.

The purpose of this paper is to provide technical support for the ecological management of rural rivers.

\section{REFERENCE}

[1] Zhang Zhanyu and Xu Cuilan, "Research on the Problems of Water and Soil Environment in Irrigation Districts and Its Countermeasures," China Rural Water and Aydropower,2002,0(4):47.

[2] Guo Shuang, "Research on Evaluation System Development of River Function Level and its Application," Dalian University of Technology, 2013.

[3] Tang Chunxi. "Computing Theory and Software Development for Design Flood of Middle or Small Catchment," Zhejiang University, 2003 .

[4] Liu Dapeng. "The study of river ecological restoration technology based on the near-natural design," Northeast Normal University, 2010.

[5] Ni Jinren and Liu Yuanyuan, "Ecological rehabilitation of damaged river system,"Journal of Hydraulic Engineering, 2006,37(9):10291037.

[6] Geoffrey Petts and Peter Calow. "River Restoration," London: Blackwell Science Ltd, 1996.

[7] Min H, Melachrinoudis E. "The relocation of a hybrid perspectives: a case study," International Journal of Management Science, 1999,27(1):75-85.

[8] Ma J, Fan Z P, Huang L H. "A subjective and objective integrated approach to determine attribute weights," European Journal of Operational Research, 1999,112(2):397-404.

[9] Jung H W, Choi B. "Optimization models for quality and cost of modular software systems," European Journal of Operational Research, 1999,112(3):613-619.

[10] WANG Ying-ming, ELHAG Taha M S, HUA Zhong-sheng. "A modified fuzzy logarithmic least squares method for fuzzy analytic hierarchy process," Fuzzy and Systems, 2006,157(23):3055-3071.

[11] Mikhailov L, Tsvetinov P, "Evaluation of services using a fuzzy analytic hierarchy process," Applied Soft Computing, 2004,5(1):2333.

[12] Tiryaki F, Ahlatcioglu B. "Fuzzy portfolio selection using fuzzy analytic hierarchy process," Information Sciences, 2009,179(1/2):5369.

[13] Shi Ruihua. "Rivers Function Zoning and River Training Mode," Dalian University of Technology, 2008. 